Article

\title{
How Can We Mitigate Power Imbalances in Collaborative Environmental Governance? Examining the Role of the Village Facilitation Team Approach Observed in West Kalimantan, Indonesia
}

\author{
Yuki Arai ${ }^{1, *}$, Maswadi ${ }^{2}$, Shenny Oktoriana ${ }^{2}$, Anita Suharyani ${ }^{2}$, Didik $^{3}$ and Makoto Inoue 4 (i) \\ 1 Research Centre for Social Systems, Shinshu University, 8304, Minamiminowa Village, \\ Nagano 399-4511, Japan \\ 2 Agribusiness Department, Faculty of Agriculture, University of Tanjungpura, Pontianak, \\ West Kalimantan 78124, Indonesia; maswadi@faperta.untan.ac.id (M.); \\ shenny.oktoriana@faperta.untan.ac.id (S.O.); anita.suharyani@faperta.untan.ac.id (A.S.) \\ 3 Agribusiness Department, University of Nadhalatul Ulama, Pontianak, West Kalimantan 78124, Indonesia; \\ aditiadidik79@yahoo.com \\ 4 Faculty of Human Sciences, Waseda University, 2-579-15, Mikajima, Tokorozawa, Saitama 359-1192, Japan; \\ makinoue@waseda.jp \\ * Correspondence: yukiarai@shinshu-u.ac.jp
}

\section{check for} updates

Citation: Arai, Y.; M.; Oktoriana, S.; Suharyani, A.; D.; Inoue, M. How Can We Mitigate Power Imbalances in Collaborative Environmental Governance? Examining the Role of the Village Facilitation Team Approach Observed in West Kalimantan, Indonesia. Sustainability 2021, 13, 3972. https://doi.org/ $10.3390 /$ su13073972

Academic Editor: Ans Vercammen

Received: 28 January 2021

Accepted: 29 March 2021

Published: 2 April 2021

Publisher's Note: MDPI stays neutral with regard to jurisdictional claims in published maps and institutional affiliations.

Copyright: (c) 2021 by the authors. Licensee MDPI, Basel, Switzerland. This article is an open access article distributed under the terms and conditions of the Creative Commons Attribution (CC BY) license (https:/ / creativecommons.org/licenses/by/ $4.0 /)$.

\begin{abstract}
Researchers have focused on collaborative governance as an effective measure to realise sustainable natural resource management through the participation of various stakeholders. However, the literature has indicated that issues such as power imbalances tend to undermine the effectiveness of collaborative governance. Powerful actors represented by the government tend to control collaborative processes and produce benefits for dominant groups, while less empowered local communities are often deprived of opportunities for livelihood improvement. Although numerous researchers have analysed the key factors that influence the processes and outcomes of collaborative governance, few have identified a concrete measure to reduce the risk of failure, particularly when managing power imbalances in developing countries. This study explored a methodology to address the power imbalances in collaborative governance based on a case study of a participatory peatland fire prevention project implemented in West Kalimantan Province, Indonesia. Semi-structured interviews and questionnaire surveys conducted with project participants suggested that measures such as establishing a joint team of government officers and villagers, providing a common facilitation training programme, training villagers as facilitators, promoting equal knowledge sharing, and allowing villagers to make their own decisions mitigated the power imbalances between the two groups.
\end{abstract}

Keywords: collaborative governance; power; facilitation; peatland fire; West Kalimantan; Indonesia

\section{Introduction}

Collaborative governance $(\mathrm{CG})$ is defined as "a governing arrangement where one or more public agencies directly engage non-state stakeholders in a collective decision-making process that is formal, consensus-oriented, and deliberative and that aims to make or implement public policy or manage public programmes or assets" [1]. CG has the potential to enhance the quality of decisions on natural resources or environmental management using comprehensive information [2-4]. It incorporates a wide variety of knowledge and experience from different stakeholders, which produces innovative ideas [5] and workable solutions [6]. CG is expected to be responsive to rapid changes at local levels, making it easier to govern diverse and dynamic socioecological systems [7]. It is also effective in resolving conflicts among stakeholders with competing values and interests because it attempts to incorporate the opinions of all parties by reducing the risk of opposition [8]. Further, CG promotes mutual understanding and generates trust and social capital, which 
helps mitigate future conflicts [9]. Even foreign, domestic, and local "outsiders" can be involved effectively in the activities of CG, and such involvement and activities are expected to provide a breakthrough in solving the issues in natural resource management [10].

However, CG has its limitations, including fundamental differences in values and ideologies, power imbalances among stakeholders, imbalances in negotiation skills, and lack of trust [9]. In reality, it is often difficult to manage discussions in an equal and transparent manner with stakeholders with differing opinions and interests [11]. This tendency is frequently observed in natural resource management, since it requires input from multiple groups with competing values and interests $[12,13]$. CG can be time-consuming for different actors to reach a consensus [14]. Existing governmental structures provide insufficient opportunities for communities to deliberate in pursuing sustainability [15]. Horizontal and vertical collaboration is difficult [16], and creating effective partnerships among policy makers and citizens for societal transformations remains a challenge [17]. Therefore, further research on learning-based, flexible collaborative platforms are necessary [18].

In particular, power imbalances have been discussed as one of the major obstacles to achieving sustainable natural resource management through CG. While "power" is defined as "the capacity of an actor to make another do something or impose his/her own will on others" [19], it also plays a positive role in realising rights or promoting synergy through partnerships [20]. Power imbalances often serve as barriers to promoting meaningful stakeholder engagement [4] by restricting the collaborative agenda [21]. Powerful actors, such as governments, often continue to control collaborative processes [22], resulting in benefits for dominant groups [23,24], which may hinder social capital development in powerless communities [25]. Elites, including government officers, tend to prevent transferring authority to local communities, which lowers the latter's empowerment [26,27]. One of the major challenges in CG is the government's unwillingness to share control over decision making [28]. Powerful communities at national levels tend to hamper multi-level collaboration with sub-national levels [29]. Even if consensus is reached by involving less powerful or marginalised actors in decision-making processes, equitable outcomes are rarely produced because of existing power structures [30]. Power imbalances could exclude the less powerful actors from decision-making processes, which may lead to a failure to reflect their interests and needs $[23,31,32]$. Power asymmetries undermine the effectiveness of synergy, trust, creativity [33], and the implementation of socially and environmentally desirable policies [21].

These issues are particularly prominent in Indonesia, where local communities have fewer opportunities to present their opinions. In general, government officers and private companies tend to have stronger influences on deciding forest management [34]. Owing to the lack of understanding among policymakers about the importance of involving communities, local communities in Indonesia remain far from being empowered despite the implementation of decentralised forest management policies for decades [35]. Indeed, Indonesian government authorities often ignore local communities' needs [36]. The disdain for traditional ecological knowledge is one of the major issues that hamper participatory forest management in Indonesia [37]. The benefits gained by local actors through collaborative forest management remain suboptimal because of elite capture and poor local governance in countries such as Indonesia [38]. Thus, to achieve sustainable, community-based natural resource management, particularly in countries like Indonesia, it is essential to identify concrete measures to mitigate power inequalities.

Local people can play a critical role in natural resource management through daily management practices and by using local, indigenous, or traditional knowledge [39]. Local knowledge obtained through a community's long experience in a particular place can complement, correct, or provide alternative perspectives to the scientific or professional knowledge of policymakers [40]. CG involving local stakeholders is expected to be an effective measure to reinforce the capacity of local governments. If local government officers and local people can effectively collaborate on natural resource management, the latter can complement the former by serving as practitioners who adopt measures to 
manage resources sustainably [41]. Thus, devolution of power to the local people is key to the success of sustainable natural resource management [26].

Although numerous studies have analysed the processes and factors that promote or hinder CG, few researchers have identified a concrete measure to realise successful CG, especially for addressing power imbalances. In particular, ensuring effective collaboration in the context of inequitable power relations remains a difficult problem to solve [30]; these issues remain poorly understood in the literature [31]. A key question in CG is how to achieve a greater balance of power among the stakeholders at different levels [42]. Cullen et al. [11] presented a two-tier collaborative forest management planning methodology that enables all stakeholders, including powerless indigenous peoples, to reach consensus. Diaz-Sarachaga suggested a way to avoid inviting authorities to promote effective stakeholder participation [43]. Reed and Abernethy [44] stressed the importance of skilled facilitators to ensure successful knowledge production by involving diverse parties. Sherriff et al. [45] stated that empowerment of powerless communities is one of the success factors for power sharing. Partidario and Sheate [46] highlighted that knowledge sharing and shared decision-making processes may create opportunities for power sharing in impact assessment. Levesque et al. [47] suggested that institutional arrangements, such as valuing good ideas from anyone during decision making, would contribute to the equalisation of power. However, these studies were mostly based on case studies conducted in industrialised countries with better governance; few examples can be found in developing countries such as Indonesia, where severe power imbalances and hierarchies still exist. In a study conducted in Myanmar, Lundsgaard-Hansen et al. [48] emphasised that a mediator can promote smallholders' participation in decision making when interests are compatible. Apgar et al. [7] suggested that participatory action research led by researcher facilitators with an emphasis on equity would help realise more equitable governance arrangements. However, considering the limited availability of skilled facilitators or mediators in developing countries, it is necessary to adopt a methodology that does not have to rely on such rare personnel.

Although these few studies have introduced ways to promote power sharing among stakeholders, more research is necessary to facilitate successful CG in the real world, particularly in developing countries, where strong power imbalances still exist and the number of skilled facilitators is limited.

To bridge this gap, we conducted a case study of a project that adopted a unique CG approach to promote effective collaboration between government officers and villagers (i.e., farmers) in Indonesia, which addressed the issue of power imbalance. This project was implemented by the Ministry of Environment and Forestry of the Indonesian government (MOEF) and the Japan International Cooperation Agency (JICA), aiming at reducing carbon emissions from peatland fires through participatory fire prevention activities. The project introduced a unique collaborative approach called the "village facilitation team" (VFT) approach, which provided abundant opportunities for government officers and villagers to work together through facilitation, knowledge sharing, and equal communication. The following section will explain the project in detail.

\section{Case Description and Objectives}

The following project was selected for the case study because it adopted a unique CG approach to promote effective collaboration between government officers and villagers in Indonesia, where a strong power structure exists. This section describes the background, outline, outcomes of the project, and objective of this study.

Tropical peatlands are among the largest reserves of terrestrial organic carbon globally [49]. Indonesia has the largest share of tropical peatlands in the world [50]. Tropical peatlands develop in areas where dead trees do not decompose because of abundant rainfall; instead, they accumulate and form a storage of carbon. However, since the early 1980s, under government policies and private companies' agricultural and forestry practices, huge areas of peatlands have been drained and trees have been cut down to develop oil 
palm and pulp plantations [51]. When peat swamp forests are logged and drained, the groundwater level drops; as a result, peatlands become susceptible to fires [52]. Moreover, local farmers follow the custom of burning land to reduce pests and weeds, and to improve productivity in the short term; fire is an inexpensive, quick, and easy method for land clearing for agricultural purposes [53]. When fire is used on drained peatlands, however, these fires often burn wildly and expand considerably [54]. Once a huge fire occurs, peatlands release an enormous amount of greenhouse gases into the atmosphere, making Indonesia one of the largest greenhouse gas emitters globally [49].

From 2010 to 2015, the MOEF implemented a technical cooperation project with support from JICA to develop a participatory peatland fire prevention method. The main target sites were the 16 villages in the Bengkayang and Kubu Raya districts in West Kalimantan Province (Figure 1), one of the major fire-prone areas of Indonesia. The objective was to enhance the capacity of governmental organisations and local communities to prevent peatland fire. The extent of achievement of this goal was evaluated based on the decrease in the number of villagers who practiced land burning in the targeted villages. This goal was achieved, since the percentage of villagers who engaged in land burning in the target villages reduced from $71.1 \%$ to $12.8 \%$ in Bengkayang District, and from $70.9 \%$ to $32.5 \%$ in Kubu Raya District, during 2010-2015 [55]. These outcomes can be attributed solely to this project since there were no other projects with similar objectives in these target areas during this period.

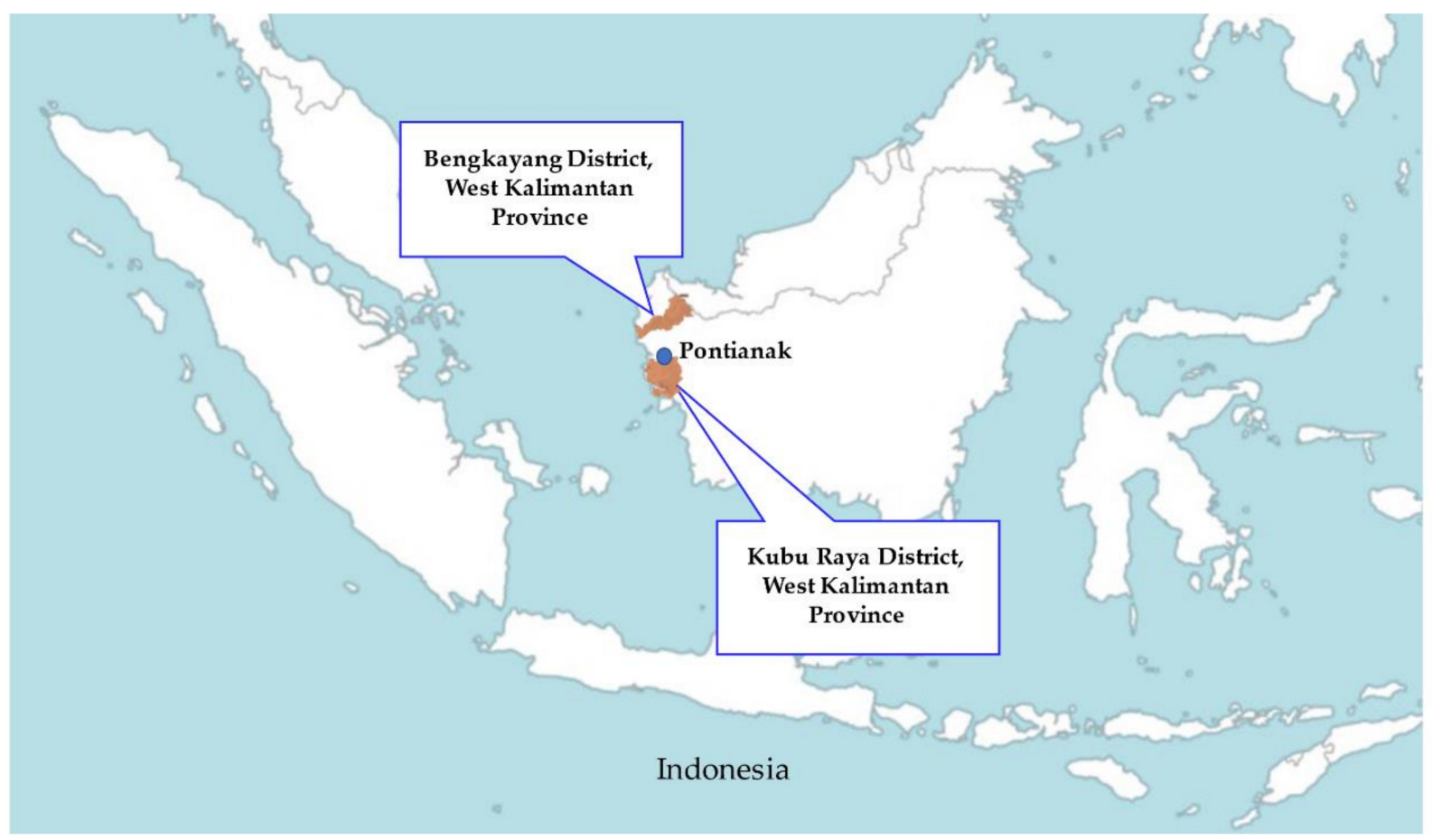

Figure 1. Map of the project's target areas (created by the first author).

The project applied a collaborative approach called the "village facilitation team" (VFT) approach to support villagers' fire prevention activities. Through this approach, the project formulated a team of six facilitators: a representative of the villagers, a village head, a village officer, two district government officers (DGOs), and a firefighter recruited by the MOEF, who is a villager. To enable these team members to serve as facilitators, the project provided an intensive facilitation training programme over approximately 10 days. The training comprised lectures, group discussions, and field exercises in actual villages that aimed to enable participants to help villagers reduce their land burning practices by sharing information and knowledge (Appendix A). The trainers were mainly Indonesian government officers and researchers with abundant experience in facilitation. 
VFT members received training not only on facilitation and consensus building, but also on land-use mapping (a participatory process that asks villagers to identify and share the landuse status and related issues with others), policies and regulations on land burning, and non-burning agricultural techniques (e.g., how to make organic fertilisers and pesticides, value-added products that can grow without the use of fire). The training programme emphasised the importance of equal and transparent discussions and included abundant information for villagers to sustain their livelihoods without practicing land burning. It placed the highest priority on training facilitators to provide sufficient opportunities for villagers to express their opinions, continue discussions until they reach consensus, and make the final decisions. These training principles are consistent with those asserted by Apgar et al. [7], which emphasise equity, stakeholder representation, distribution of authority, and accountability. In addition, trainers stressed on the importance of initiating discussions that did not focus on fire issues. Instead, they included topics directly related to villagers' livelihoods through land-use mapping, since villagers used to have little interest in fire prevention. All team members had to facilitate meetings with farmers to improve their practical communication and facilitation skills. Subsequently, these team members, who were now trained facilitators, visited the 16 target villages and facilitated villagers' discussions on reducing fires using this community-based approach. These meetings were called "VFT meetings".

The following is the typical process of the discussions held during VFT meetings. First, facilitators started discussions on topics related to land use and livelihood. Usually, villagers were asked to create a land-use map to illustrate their agricultural and forestry practices, as well as land ownership and land-use boundaries. Second, using these maps, facilitators asked villagers to identify concerns regarding land-use practices and discuss how they could improve the situation. For example, in one village, villagers discussed how to produce value-added products (e.g., banana cake) to generate more income. During these discussions, villagers occasionally mentioned the use of fire in their agricultural practices, and facilitators gradually shared information on the risks of fire use. Since the government has set legal punishments for the use of fire, villagers can be arrested, and a huge penalty can be imposed if the police find them using fire. Although facilitators did not force villagers to stop using fire, they gently shared the information for their reference.

When villagers became aware of such legal punishments, they started discussing methods to manage the risks of using fire, perhaps because they wanted to avoid punishment. In many cases, the top priority for villagers was their livelihood and income generation. Since fire used to be an integral part of their farming practices, it was difficult to stop using it suddenly. Thus, farmers had to think about how they could reduce fire use and sustain their livelihood simultaneously [56].

As a result, most target villages requested that facilitators (i.e., DGOs with expertise in agriculture) provide training on non-burning agricultural techniques (e.g., making organic fertilisers or producing products that grow without fire usage). Moreover, the villagers in all 16 target villages started developing self-rules on fire use, some of which eventually became official village ordinances. Thus, they strived to prevent legal punishments while attempting to identify alternative methods to sustain their livelihoods. As the VFT approach allowed all interested stakeholders to participate and make their voices heard, and facilitated knowledge sharing and mutual learning processes, it basically aligns with the concept of "knowledge brokerage" explained by Partidario and Sheate [46].

The VFT approach is a unique CG approach in two aspects. First, it is uncommon for DGOs and local villagers to develop a single team and receive the same training programme, particularly in countries such as Indonesia, that have strong hierarchies and a huge educational gap among the population. Second, in other projects, facilitators tend to be individuals such as government officers, consultants, or NGO staff, who are often considered as outsiders by local communities. In this project, villagers themselves became facilitators, and more than one villager served as a facilitator. These two points made the VFT approach a unique method for promoting CG. 
The objective of this case study is to examine how collaboration between DGOs and villagers was conducted and how power relations between powerful and less empowered stakeholders were observed in the aforementioned project. To achieve this goal, we explored the following two research questions: (1) how did the project participants perceive the CG approach with a strong emphasis on facilitation and knowledge sharing (i.e., VFT approach) and (2) how did the project participants (particularly villagers) perceive the relationships with DGOs? To answer these research questions, we used the following analytical framework.

\section{Methods}

\subsection{Analytical Framework}

Ansell and Gash [1] reviewed 137 cases of CG from the literature and concluded that three starting conditions and two influential factors play a significant role in the collaborative process and in producing the outcomes of CG. These are (A) power-resourceknowledge asymmetries, (B) incentives for and constraints on participation, (C) prehistory of cooperation or conflict (initial trust level), (D) institutional design (participatory inclusiveness, forum exclusiveness, clear ground rules, and process transparency), and (E) facilitative leadership (including empowerment), respectively. Our analysis was based on the CG model developed by Ansell and Gash [1] because it is a comprehensive framework that encompasses the literature on CG case studies, researchers in relevant fields have frequently cited this article, and the model smoothly aligns with the target project's activities, which pursued successful implementation of CG.

However, this model has certain limitations. It is largely built on case studies from Western industrialised countries and does not consider alternatives when conditions A-E are not met. In developing countries, conditions A-E, particularly A, are often unfavourable. The literature has suggested that a strong imbalance in power relations is one of the major obstacles to the successful implementation of the collaborative approach [9]. However, this model does not clarify how we can mitigate power or knowledge asymmetries. Therefore, the present study focused on the role of external factors and processes that may improve or strengthen these conditions and factors, particularly condition A, to ensure the successful implementation of CG.

To adjust the analytical framework according to our research questions, we added the following two components (i.e., facilitation and knowledge sharing), which have been suggested to contribute to the better management of power relationships. For instance, Apgar et al. [7] highlighted that facilitators can help build more equitable governance arrangements, while Partidario and Sheate [46] explained that effective knowledge sharing can create opportunities for power sharing. As mentioned earlier, these two principles were incorporated in the VFT approach. We hypothesised that the approach can improve the starting conditions of Ansell and Gash's CG model [1] (particularly condition A). Thus, our study assessed the role of the VFT approach in achieving CG, particularly focusing on the process of power mitigation based on the framework that combined the Ansell and Gash's model [1] and the findings of Apgar et al. [7] and Partidario and Sheate [46] (Figure 2). 


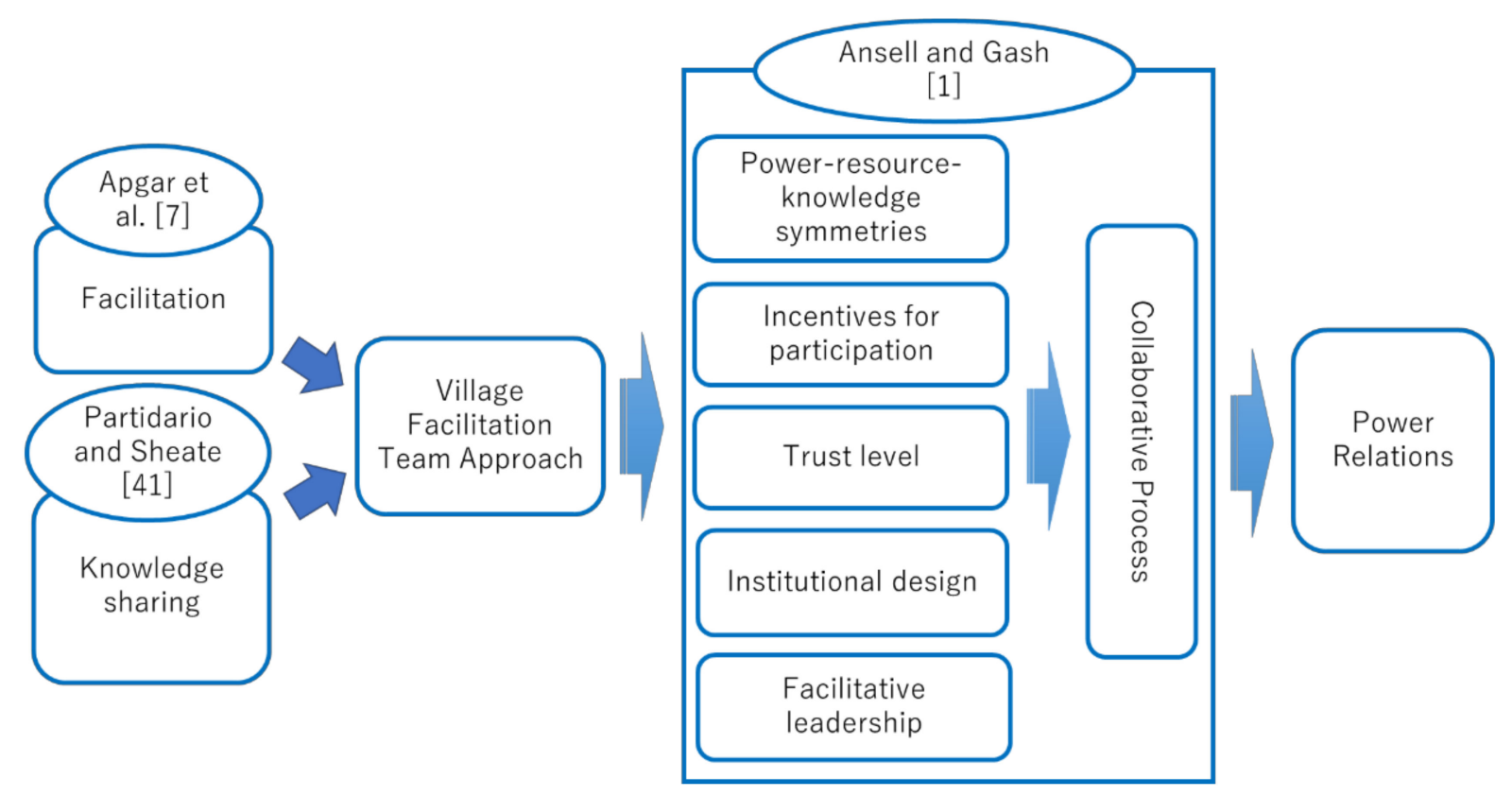

Figure 2. Analytical framework.

\subsection{Data Collection}

This case study was conducted from October 2017 to March 2018 using a combination of qualitative and quantitative methods. The target areas of this research were Kubu Raya District and Bengkayang District in West Kalimantan Province, Indonesia, which encompasses the 16 target villages in which the VFT approach was implemented. Among these 16 villages, eight villages (Limbung, Mekar Sari, Rasau Jaya I, and Rasau Jaya Umum in Kubu Raya District, and Sungai Jaga A, Sungai Raya, Sungai Duri, and Sungai Pangkalan II in Bengkayang District), which are representatives of the socioeconomic and cultural diversity of the 16 target villages, were selected for the questionnaire survey. Four villages out of the eight villages (i.e., Limbung and Mekar Sari in Kubu Raya District, and Sungai Jaga A and Sungai Raya in Bengkayang District) were randomly selected as target villages for the interview survey.

The majority of the villagers in the target villages were farmers ( $89 \%$ of the respondents). The major products in these villages include rice, maize, rubber, pepper, coconut, chillies, pineapples, and aloe. Nearly $100 \%$ of the farmers were individual landowners, owning one or two hectares of land. The majority of the villagers were elementary school graduates $(58 \%)$ and a small proportion had studied at junior $(18 \%)$ or senior high school (20\%).

First, semi-structured interviews were conducted in the four villages with 20 randomly selected informants (participants of VFT meetings) to explore their perceptions of the roles of the VFT approach in relation to the analytical framework (Appendix B). Five informants were selected from each target village. Among them, eight informants were VFT members and 12 were non-VFT members. In-depth, semi-structured interviews lasting 1-1.5 h were conducted with each informant.

Subsequently, the questionnaire survey was conducted to 200 randomly selected respondents in eight villages ( 25 respondents from each village). The questionnaire was developed based on the results of the semi-structured interviews and analytical framework described earlier. The questionnaire also incorporated findings from the literature focusing on effective methods for facilitation as well as equal and collaborative decisionmaking processes [57-70]. It comprised 34 questions (23 questions were for all respondents; 11 questions were only for VFT members) that aimed to quantify respondents' perceptions of each activity related to the VFT approach using a four-point Likert scale (4: Strongly 
agree, 3: Agree, 2: Disagree, 1: Strongly disagree) (Appendix C). The 11 questions were prepared for the 29 VFT members to evaluate their perceptions of the VFT training programme. Thus, 29 VFT members answered 34 questions, while the other 171 participants (who did not join the VFT training programme) only responded to 23 questions. Before starting the questionnaire survey in the target villages, we conducted a pre-test with five randomly selected respondents in a non-target village to confirm the relevance and applicability of the questions. The questionnaire was finalised based on the results of these pre-tests.

Although the questionnaires were written in Indonesian, the Indonesian co-authors met all respondents individually and provided explanations on the study's purpose, obtaining informed consent. As they explained the exact meaning of each question, we could obtain accurate data. While the first author was an officer at the JICA Indonesia Office in 2012-2014 and was in charge of the natural resource management sector, he did not participate in the interviews or questionnaire surveys in the field to avoid biased responses. All the surveys were conducted by the Indonesian co-authors, who are researchers at the University of Tanjungpura in Pontianak, West Kalimantan, Indonesia. Because the co-authors were independent of the Indonesian government and JICA, respondents could freely express their honest impressions of the project activities. In addition, all interviews/questionnaire surveys were conducted individually (only with the surveyor and respondent), so that respondents did not have to be polite when expressing their opinions. All respondents were asked to use the four-point scale and the co-authors recorded the answers on the questionnaire sheet.

The limitation of this method is that it lacks statistical representativeness. For instance, we did not compare people's perceptions between villages with and without project interventions. In addition, as this is a single case study, the findings can be influenced by a specific context that existed in the particular project or target area. However, combining the questionnaire and interview data enabled us to understand the overall picture of the local peoples' perceptions and an in-depth perspectives of each project participant.

\section{Results and Discussions}

This section presents the findings from the questionnaire and interview survey as well as discusses the implications. This study examined how CG can be promoted, particularly through the mitigation of power imbalances, based on the following two research questions: (1) how did the project participants perceive the CG approach with a strong emphasis on facilitation and knowledge sharing (i.e., VFT approach) and (2) how did the project participants (particularly villagers) perceive the relationships with DGOs? As mentioned in Section 2, we confirmed that the VFT approach includes the facilitation principles asserted by Apgar et al. [7] and concept of knowledge sharing stated by Partidario and Sheate [46]. The following section describes how the project participants perceived the VFT approach as well as the relationships with DGOs based on the analytical framework. (All the questionnaire survey results can be seen in Appendix C.)

\subsection{Power-Resource-Knowledge Asymmetries}

The survey results indicated that the strong power inequalities that existed at the early stages of the project were alleviated through the facilitation training and series of VFT meetings. In total, nearly $80 \%$ of facilitation training participants felt nervous at the early stages because they thought that their knowledge and skills were insufficient as compared with those of other participants, particularly DGOs; $67 \%$ of all respondents felt the same way in the early stages of VFT meetings (Figure 3). Further, $76.5 \%$ of the respondents felt nervous about joining meetings with people they did not know well, particularly DGOs (Figure 3). Interviewees confessed that villagers generally felt nervous in front of DGOs because such discussions on village activities rarely occurred with both parties at the same table. 
At the early stages of the Village Facilitation Team meetings, I felt nervous because I didn't have enough knowledge and skills compared to the other participants, particularly district government officers.

At the early stages of the Village Facilitation Team meetings, I felt nervous because there were some people whom I didn't know well, particularly district government officers.

In case some participants had difficulties in understanding the contents of the discussions, appropriate support was provided by Village Facilitation Team members.

At the later stages of Village Facilitation Team meetings, there were little gaps in knowledge or skills among participants.

At the later stages of the Village Facilitation Team meetings, I could express. my opinions freely without being nervous.

Because some village representatives facilitated the meetings as Village Facilitation Team members, I felt comfortable in expressing my opinions.

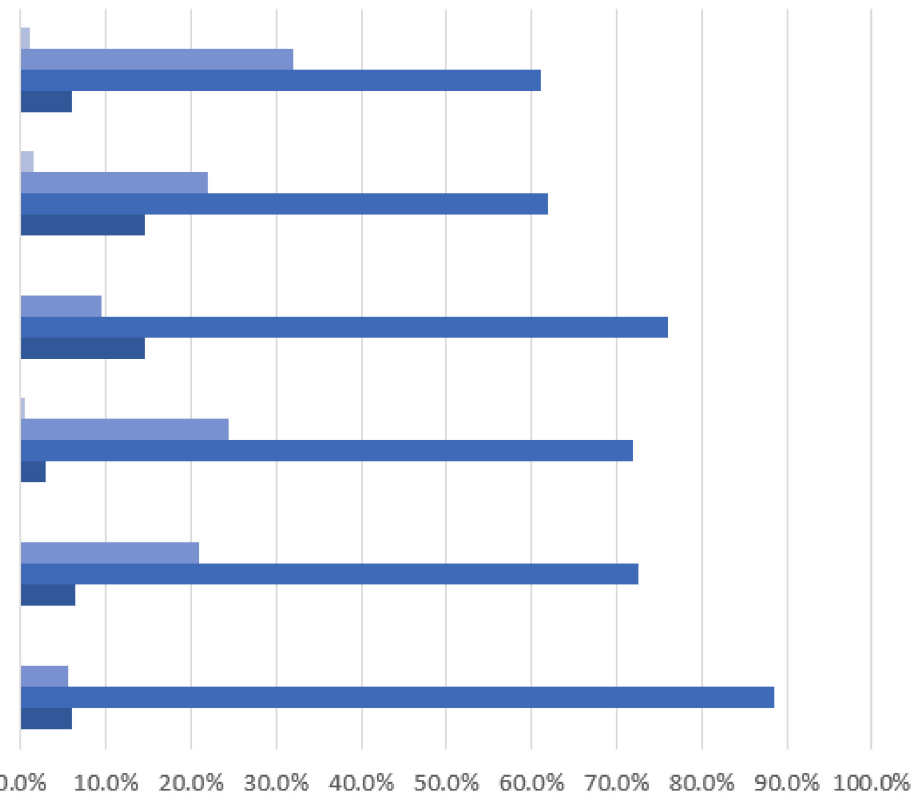

w Percentage of Respondents 1: Strongly disagree $\square$ Percentage of Respondents 2: Disagree

- Percentage of Respondents 3: Agree

- Percentage of Respondents 4: Strongly agree

Figure 3. Respondents' perceptions of the Village Facilitation Team approach focusing on power/resource/knowledge asymmetries $(n=200)$.

All VFT respondents (i.e., DGOs and village representatives) acknowledged that those who received training had equal opportunities to obtain knowledge and skills, and that they acquired a certain amount of new knowledge and practical skills through the facilitation training. Almost $80 \%$ of the VFT respondents admitted that appropriate support was provided by the trainers to less-educated participants in case they had difficulties in keeping up with the training. At the end of the facilitation training, nearly $80 \%$ answered that there was little gap in knowledge or skills among the participants, including the DGOs.

In addition, a vast majority of the respondents $(98 \%)$ perceived that information and knowledge were shared equally with all participants during VFT meetings, and $91.5 \%$ acknowledged that appropriate support was provided by VFT members when participants had difficulties in understanding the discussions (Figure 3). Interviewees reported that VFT members avoided using scientific or technical terms, and they provided support to translate or visualise the main discussion points for participants unfamiliar with the Indonesian language. Further, $64 \%$ of the respondents answered that they understood almost everything about the discussion topics during VFT meetings.

In the later stages of VFT meetings, $75 \%$ of the respondents perceived that there were small gaps in participants' knowledge and skills, including those of DGOs (Figure 3). Further, 79\% responded that they could express their opinions freely, without being nervous in the later VFT meetings despite the presence of DGOs (Figure 3). Nearly all respondents $(94.5 \%)$ answered that they felt comfortable with expressing their opinions because some village representatives facilitated the meetings as VFT members (Figure 3). It is important to note that $81 \%$ of the survey respondents were friends, families, relatives, or neighbours of the villagers trained to become facilitators.

These findings suggested that the VFT approach played an important role in mitigating the knowledge and power imbalances between powerful and powerless actors (i.e., DGOs and villagers, respectively). We presume that the negative power of DGOs defined by Prabowo, Maryudi, and Imron [19] was alleviated through external interventions, while the positive power of villagers to realise their rights, as explained by Gaventa [20], was strengthened. Importantly, the VFT approach supported less empowered participants (e.g., by avoiding technical terms, visualising the main discussion points, and translating 
them into local languages), which seemed to help mitigate power relations by enhancing the capacities of less-educated villagers. We emphasise the significance of this effort in avoiding the risk of exacerbating the vulnerabilities of powerless actors in the absence of appropriate support, as claimed by Begg [70]. We presume that "knowledge brokerage," as suggested by Partidario and Sheate [46], was realised through the aforementioned equal knowledge sharing that occurred under the VFT approach.

The existence of villager facilitators may have also mitigated the power relations between the two stakeholders, as the VFT members (i.e., facilitators) were villagers of the target villages. As Eversole [40] and Tsubouchi [71] asserted, professionals or development projects are foreign to local communities when facilitators are individuals from outside the village (e.g., government officers, consultants, or NGO staff). Villagers may have been unable to express their feelings and opinions honestly during discussions if facilitators had been outsiders. However, in this project, three of the six VFT team members were representatives from the target villages. Although villagers tend to become nervous in front of government officers, it was relatively easy for them to join the discussions because VFT meetings were also led by villager facilitators whom they knew well.

\subsection{Incentives for and Constraints on Participation}

The survey results indicated that the majority of the project participants had certain incentives to join the meetings, and no serious constraints were observed. Most participants freely participated in VFT meetings to obtain knowledge and maintain interpersonal relationships. A total of $97 \%$ of the respondents answered that they participated in VFT meetings to obtain useful information or knowledge related to their livelihoods (Figure 4), and $87.5 \%$ participated because they were reluctant to miss the opportunity to obtain important information. Interviewees mentioned that they expected to learn about agricultural and forestry techniques, including measures to improve productivity, manage pests and weeds, and produce value-added products. Some also reported experiencing anxiety about missing essential information on land burning rules and about incurring disadvantages if they were unaware of the laws and regulations.

I participated in Village Facilitation Team meetings to obtain useful information or knowledge related to my livelihood.

I participated in Village Facilitation Team meetings to maintain good relationships with friends, neighbors, family members, relatives, village representatives, or other villagers.

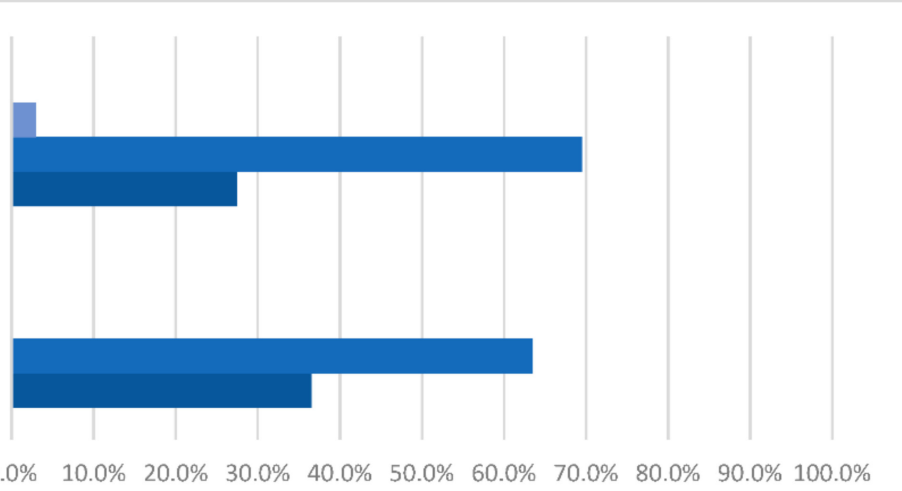

nercentage of Respondents 1: Strongly disagree Percentage of Respondents 2: Disagree

- Percentage of Respondents 3: Agree

- Percentage of Respondents 4: Strongly agree

Figure 4. Respondents' perceptions of incentives for participating in Village Facilitation Team meetings $(n=200)$.

Moreover, all respondents answered that they participated in VFT meetings to maintain good relationships with friends, neighbours, family members, relatives, village representatives, and other villagers (Figure 4). Some interviewees referred to the importance of helping each other in the community. They acknowledged that, since they were economically poor, less educated (i.e., the majority were elementary school graduates), and dependent on agriculture, maintaining good relations with other community members is vital for their survival. 
In contrast, interviewees reported problems related to access and time constraints when joining VFT meetings. A few respondents mentioned that they had difficulties in reaching the meeting place because of the limited availability of fuel. However, this concern was mostly resolved, at least during the project period, because the project provided financial support for villagers to purchase gasoline for their motorcycles. Another constraint was that farmers were often too busy with their daily agricultural activities. However, since VFT meetings were usually organised in the evenings, when most farmers had finished their work in the field, sufficient time was allocated. Therefore, no significant constraints to using the VFT approach were observed.

\subsection{Prehistory of Cooperation or Conflict (Initial Trust Level)}

The survey results indicated that there had been no serious conflicts among the villagers and DGOs, and that the VFT approach may have strengthened the trust among them. Most respondents (99\%) answered that they did not experience conflicts with other participants, including DGOs, before joining VFT meetings (Figure 5).

Before joining Village Facilitation Team meetings, I did not experience conflicts with other participants.

The trainings for non-burning agriculture techniques (e.g. organic fertilizers, organic pesticides) strengthened relationships between Village Facilitation Team members (including district officers) and other participants.

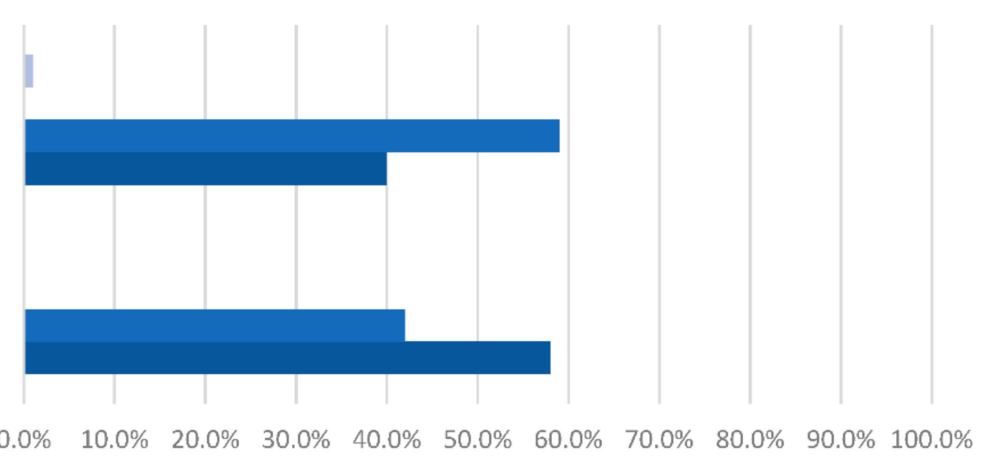

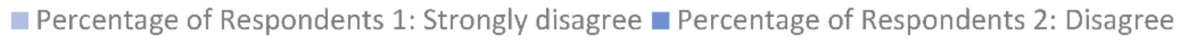

Figure 5. Respondents' perceptions of prehistory of conflict and training on non-burning agricultural techniques $(n=200)$.

Villagers and DGOs perceived that they strengthened trustworthy relations by participating in the facilitation training and VFT meetings for one or two years as a team. All VFT respondents who received facilitation training replied that they got to know each other better; interviewees mentioned that participants were together for almost the entire duration of the 10-day training programme, which helped them build trust. Overall, $86 \%$ of the VFT respondents perceived that they were able to build mutual trust with other participants by the end of the facilitation training.

The survey results also indicated that training on non-burning agricultural techniques helped strengthen the relationships between DGOs and other villagers (Figure 5). All agreed (58\% of the respondents "strongly agreed") on this point. Most interviewees perceived that DGOs' efforts to improve villagers' livelihoods enhanced their feelings of trust in the former.

These results indicate that the facilitation training and DGOs' provision of training on non-burning agricultural techniques helped build trust between DGOs and villagers. Developing trust can improve collaboration through honest participation [72]. Moreover, Ran and Qi [73] suggested that trust building could positively influence the management of power relations. While the literature indicates that government officers in Indonesia rarely take local people's needs into consideration [36], such trustworthy relationships may have offered villagers more opportunities to express their concerns or requests to government officers. Although our data may be insufficient to determine whether this trust alleviated 
power imbalances, villagers had better chances to communicate with government officers based on the existence of trusting relations.

4.4. Institutional Design (Participatory Inclusiveness, Process Transparency, Clear Ground Rules, and Forum Exclusiveness)

The study findings demonstrated that the VFT approach mostly fulfilled the components of a sound institutional design suggested by Ansell and Gash [1]. Although some villagers mentioned that VFT meetings were often attended by group leaders assigned by the village heads or village offices, $71.5 \%$ of the respondents perceived that VFT meetings were open to anybody interested in joining the discussion (Figure 6). Not only the key stakeholders, such as the leaders of farmers' or women's groups, but also elders, young people, and schoolteachers participated in these meetings. Some interviewees mentioned that women were also able to join VFT meetings if they wanted to participate. A vast majority $(96 \%)$ agreed that most participants actively joined VFT meetings. The decisions made during VFT meetings and the progress of activities were reported and shared with relevant stakeholders, including the district government, village office, MOEF, and villagers.

Village Facilitation Team Meetings were open to anybody who was interested in joining the discussions.

All participants were treated equally during Village Facilitation Team meetings.

During Village Facilitation Team meetings, all participants' opinions were listened to and respected by other participants.

Village Facilitation Team members made effots to build consensus by combining all participants' opinions.

Most important decisions were made by villagers, not by Village Facilitation Team members.

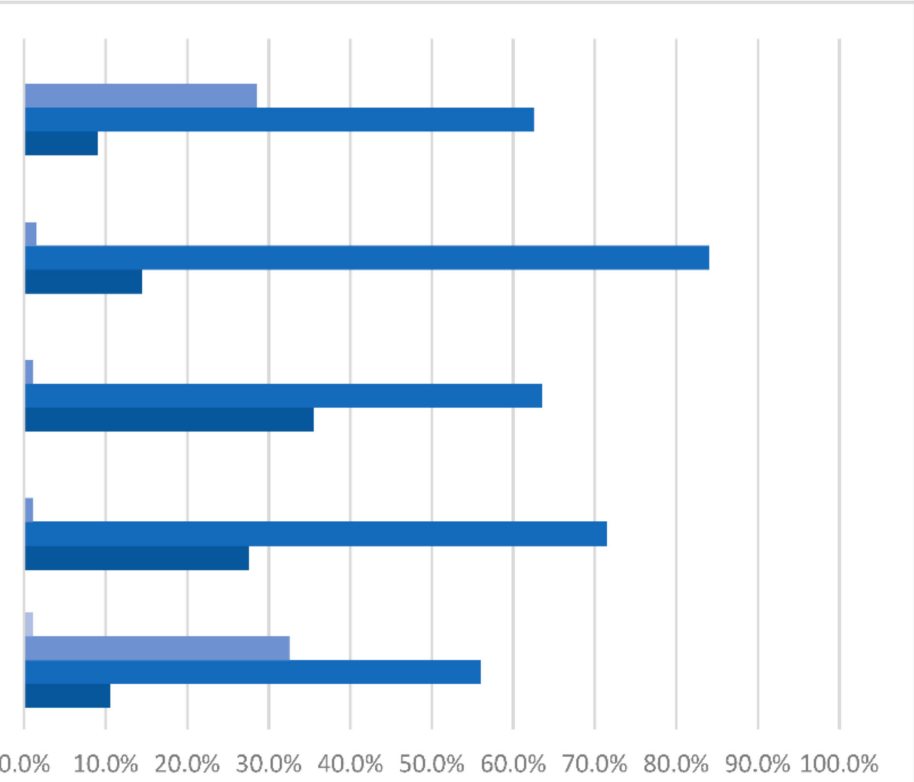

- Percentage of Respondents 1: Strongly disagree $\square$ Percentage of Respondents 2: Disagree

- Percentage of Respondents 3: Agree

- Percentage of Respondents 4: Strongly agree

Figure 6. Respondents' perceptions of the Village Facilitation Team approach focusing on institutional design $(n=200)$.

Further, $98.5 \%$ of the respondents acknowledged that all participants were treated equally during VFT meetings (Figure 6). Nearly all respondents (99\%) reported that all participants' opinions were listened to and respected by other participants, regardless of their occupation, gender, or educational level (Figure 6). Interviewees referred to the fact that VFT members or trainers supported participants from ethnic minority groups by translating their explanations into local languages when the latter were unfamiliar with Indonesian. Nearly $90 \%$ of the respondents perceived that participants in VFT meetings made efforts to respect other participants' opinions even if they were different from their own. Interviewees mentioned that it was sometimes difficult to reach consensus during VFT meetings. On such occasions, VFT members made efforts to listen to participants ideas individually, respecting their opinions as much as possible, and they attempted to arrive at a point on which all attendants could agree. A vast majority of the respondents $(99 \%)$ acknowledged that VFT members made efforts to reach consensus by combining 
all participants' opinions (Figure 6). In total, 86\% acknowledged that decisions on the topics of VFT meetings were made when most participants were in attendance and $66.5 \%$ perceived that most important decisions were made by villagers rather than by VFT members (Figure 6). Respondents acknowledged that, for some decisions, it was essential to obtain additional approval from the district government after VFT meetings because official approval was necessary for budget allocation. This might explain why $33.5 \%$ of the respondents perceived that important decisions were not necessarily made by the villagers.

Nearly $60 \%$ of the respondents agreed that there were clear ground rules on how to participate in discussions when joining VFT meetings. For instance, some interviewees explained that paying attention, listening to other participants' ideas, and not talking or interrupting while others were speaking were some of the ground rules introduced at VFT meetings that helped participants listen to other people's opinions carefully and express their own ideas. Regarding forum exclusiveness, as we confirmed that no other collaborative project or activities with similar goals were being conducted in the target villages, this component was satisfied.

The above findings suggest that VFT members were trained enough to allow villagers to discuss, agree, and make decisions in an equal and transparent manner through effective facilitation. Although it is generally common for Indonesian government officers to make decisions on natural resource management [34,37], the fact that VFT members, including DGOs, were trained to allow villagers to make their own decisions allowed the latter to influence the decision-making processes. This process may have reduced the gaps in authority, which has been identified as one of the sources of power [33]. Continuing such equal and transparent communication in the long run thus mitigated the power imbalances that existed before.

\subsection{Facilitative Leadership (Including Empowerment)}

The results showed that villagers who were less educated and less empowered were able to obtain facilitation skills and contribute to enhancing facilitative leadership in the target villages. All VFT respondents agreed that participants had equal opportunities to obtain knowledge and skills and that they were able to obtain an abundance of new knowledge and practical skills through the facilitation training (Figure 7). Furthermore, the majority of the VFT respondents (nearly $90 \%$ ) acknowledged that the training helped them obtain skills in combining different people's ideas and building consensus. In fact, $99 \%$ of the VFT meeting participants perceived that the VFT members made efforts to build consensus by considering all participants' opinions.

During the facilitation training, all the participants had equal opportunities to obtain knowledge and skills.

Through the facilitation training, I could obtain abundant new knowledge and practical skills.

In case some participants had difficulties in keeping up with the training program, appropriate support was provided by the trainers.

At the end of the facilitation training, there were little gaps in knowledge or skills among participants.

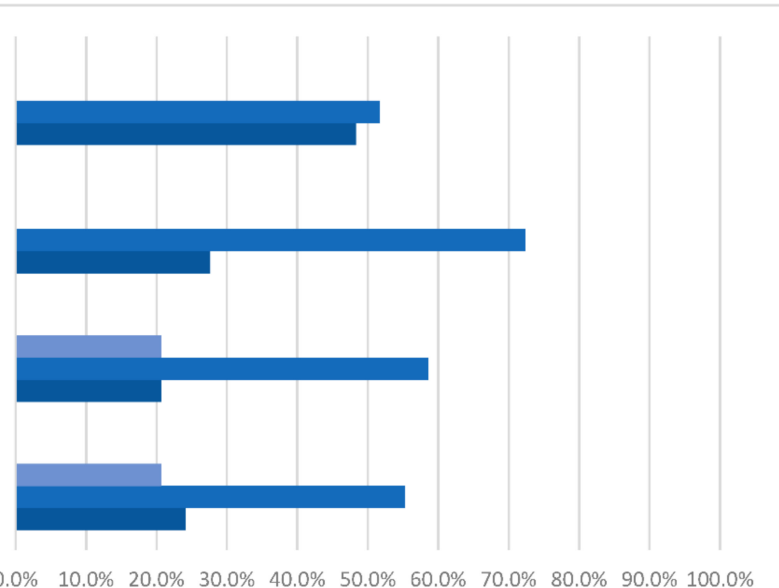

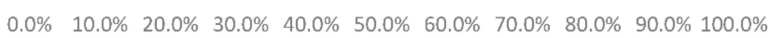

घercentage of Respondents 1: Strongly disagree — Percentage of Respondents 2: Disagree

- Percentage of Respondents 3: Agree

Figure 7. Village Facilitation Team members' perceptions of the facilitation training programme $(n=29)$. 
Almost $80 \%$ of the training participants answered that appropriate support was provided by trainers when participants had difficulties keeping up with the programme (Figure 7). The interviewed VFT members explained that trainers attempted to avoid the use of scientific or technical terms to ensure that all participants could understand the content. These forms of assistance may have enabled less-educated villagers to increase their capacity to become eligible facilitators, and could have led to their increased empowerment. Further, the survey results indicated that nearly $80 \%$ of the training participants thought that the gap in knowledge or skills among participants including DGOs was negligible at the end of the facilitation training (Figure 7).

Because both government officers and villagers participated in the same facilitation training programme, gaps in knowledge and skills may have been minimised. Although some less-educated villagers seemed to experience difficulties in keeping up with certain parts of the training, trainers' efforts to limit the use of scientific and technical terms, visualise explanations with drawings, and translate explanations into local languages helped villagers obtain a similar level of knowledge and skills as DGOs by the end of the facilitation training.

\subsection{Collaborative Process}

The survey findings suggested that the VFT approach went through the major processes explained in Ansell and Gash's CG model [1], which are "face-to-face dialogue," "trust building," "commitment to process," "shared understanding," and "intermediate outcomes." First, the VFT members regularly joined the village meetings and had faceto-face discussions almost every month, which continued for 1.5-2 years in most villages. Second, as mentioned earlier, villagers and VFT members had abundant opportunities to communicate with one another through VFT meetings and other relevant activities, which promoted mutual understanding and contributed to trust building. In particular, as all respondents acknowledged that training on non-burning agricultural techniques helped strengthen the relationship between DGOs and other villagers, it is evident that identifying issues together and cooperating to improve villagers' livelihoods played an important role in building trust.

Third, the majority of the respondents agreed that VFT members respected all participants' opinions, and that the villagers themselves made most of the decisions during meetings. These findings align with the arguments proposed by Ansell and Gash [1], that respecting stakeholders' interests, and ensuring fair and transparent procedures are critical for strengthening commitment. Fourth, interviewees shared a common perception that VFT meetings were conducted with a common goal of achieving fire reduction and livelihood improvement. In addition, the majority of the respondents answered that information was equally shared, less-educated participants received adequate support, and most participants understood and actively joined the discussions. Finally, discussions on non-burning agriculture techniques produced intermediate outcomes such that $90 \%$ of the respondents obtained ideas about how they could tackle the issue of fire. Thus, the present results indicate that the VFT approach satisfied the five components of the collaborative process.

Our findings are in line with those reported by Apgar et al. [7], which stressed that promoting equity, trust, and shared analysis through facilitation helps build more equitable governance. As suggested by Riggs et al. [74], these external interventions may have enabled the creation of a platform that allowed vertical and horizontal communication outside formal government structures.

\section{Conclusions}

CG has the potential to realise sustainable natural resource management by enabling various stakeholders to engage in management practices. Although researchers have studied numerous cases of CG, and power has been pointed out as a major challenge in CG, few studies have discussed how to mitigate the power imbalances in CG, particularly in developing countries with strong hierarchies, such as Indonesia. Ensuring effective 
participation in the context of inequitable power relations remains a difficult issue [30], and it is still poorly understood in the literature [31].

This study examined the role of a unique CG approach that aimed to mitigate power imbalances among the stakeholders of a peatland fire prevention project conducted in West Kalimantan, Indonesia, with support from JICA. While similar projects have rarely been observed in countries such as Indonesia, this project attempted to build a collaborative team of DGOs (i.e., powerful stakeholders) and ordinary villagers (i.e., unempowered stakeholders), have them participate in the same facilitation training programme, trained the village representatives as facilitators, and let them conduct the activities as a team for one or two years, while consistently emphasising equal knowledge sharing and shared decision making through facilitation. We argue that these attempts alleviated the asymmetries in knowledge and power, which are identified as one of the starting conditions in Ansell and Gash's CG model [1]. The survey results demonstrated several positive outcomes, particularly in equal knowledge sharing, consensus-based and shared decision making, and trust building.

Our results also highlighted that the existence of villager facilitators served as a catalyst in reducing the power gaps between government officers and villagers. Because three out of six VFT members were villagers, it was easier for the villager participants to join the discussions even with DGOs' attendance. The fact that the majority of the respondents who used to feel nervous in the presence of government officers were able to express their opinions freely after participating in the series of VFT meetings over one or two years illustrates that power imbalances were mitigated through this project's approach Although some less-educated villagers seemed to have had difficulties in keeping up with the training or discussions, the survey results suggested that VFT members' assistance alleviated such obstacles. It is important to afford sufficient consideration to less-educated stakeholders' needs to avoid the risk of further marginalising them in the absence of appropriate support.

We conclude that the VFT approach played an important role in mitigating the power imbalances that existed between government officers and villagers by building a joint team of DGOs and villagers, providing a common facilitation training programme, promoting equal knowledge sharing, providing appropriate support for the powerless, training villagers as facilitators, and allowing villagers to make their own decisions.

The major contribution of our study was that it suggested a concrete measure and process for mitigating power imbalances in CG; we argue that Ansell and Gash's CG model [1] with appropriate external interventions to improve the conditions and factors can contribute to a better management of power relations. We recommend that practitioners who conduct projects through collaborative approaches consider building joint teams of stakeholders and provide the same training to all stakeholders, with sufficient support for the powerless. Training less-empowered stakeholders as facilitators is also recommended.

This study has three limitations. First, since it is a single case study, the observations can depend on a specific context and the outcomes cannot be generalized. Second, the number of stakeholders were limited to DGOs, village heads, village officers, firefighters (who are mostly villagers), and other villagers, while central government, private companies, and NGOs were not represented. Third, the involved stakeholders basically shared common objectives such as income generation and social welfare improvement, and thus severe conflicts were unlikely to occur. If large-scale oil palm industries were one of the major stakeholders, the outcomes may have been different.

Future research should focus on examining the effectiveness of these approaches in cases with a greater number of stakeholders with different interests, such as oil palm industries and central government officers. As this study was conducted with a limited number of Indonesian people in West Kalimantan Province where they share similar socioeconomic, political, and cultural backgrounds, the effectiveness and applicability of this approach should be tested in other parts of the world. In particular, more studies need to examine cases with conflicts where stakeholders' interests are non-compatible. Further, as 
our study mainly examined the issues of power asymmetry, which is one of the starting conditions in Ansell and Gash's [1] model, more studies could address the issues of the lack of incentives and lack of trust among stakeholders. These studies would promote effective CG in broader contexts. Although further research is necessary, this study can help overcome the major obstacles to achieving successful CG in developing countries.

Author Contributions: This research was initiated by Y.A. and M. Then, M., S.O., A.S., and D. conducted the field data collection, and summarised and analysed the survey data. The writing process was led by Y.A. in collaboration with M.I. All authors participated in the revision process. All authors have read and agreed to the published version of the manuscript.

Funding: This research was funded by the JICA Ogata Sadako Research Institute for Peace and Development as a part of its efforts to promote research on JICA-supported projects worldwide. The findings and conclusions described in this article are those of the authors and do not reflect the views of JICA or the research institute.

Institutional Review Board Statement: The study was conducted according to the guidelines of the Declaration of Helsinki, and approved by the institutional review board of JICA (27th September 2017).

Informed Consent Statement: Informed consent was obtained from all subjects involved in the study.

Data Availability Statement: All the data related with this study is presented in the manuscript and Appendix D.

Acknowledgments: We would like to thank the JICA Ogata Sadako Research Institute for Peace and Development for providing financial support for this research. We would also like to express our gratitude to the Ministry of Environment and Forestry of Indonesia, Kubu Raya District, Bengkayang District, and all villagers who kindly accepted our field study. We also wish to express our sincere thanks to Hiromitsu Kuno and Shuichi Hirayama, who were the project experts, and to JICA for their dedicated support for our surveys. Finally, we would like to thank Hideyuki Kubo and Tomonori Yokouchi for their meaningful advice.

Conflicts of Interest: The authors declare no conflict of interest.

Appendix A. Outline of the Training Programme for the Village Facilitation Team

Table A1. Outline of the Training Programme for the Village Facilitation Team.

\begin{tabular}{ccc}
\hline Day & Programme & Style \\
& Introduction to Forest and Land Fire & Exercise \\
& Climate Change Mitigation through Forest and Land Fire & Prevention \\
Day 1 & Laws and Regulations on Forest and Land Fire & Lecture \\
& Basics of Facilitation and Communication, Concept of & Lecture \\
& Village Facilitation Team & Lecture/Exercise \\
Day 2 & Participatory Land Use Mapping & Lecture \\
& Making a Village Land Use Map & Exercise \\
& Land Management Planning & Exercise \\
& Developing Village Ordinance for Fire Prevention & Exercise \\
\hline Day 3-5 & Collecting Information of Villages & Field Exercise \\
& Interview to Villagers and Farmer Groups & Field Exercise \\
& Implementing Focus Group Discussions & Field Exercise \\
& Facilitation of Village Meetings & Field Exercise
\end{tabular}


Table A1. Cont.

\begin{tabular}{|c|c|c|}
\hline Day & Programme & Style \\
\hline \multirow{7}{*}{ Day $7-8$} & Agricultural Practices without Land Burning & Lecture \\
\hline & Techniques for Making Organic & \\
\hline & Fertilizers/Pesticides/Herbicides & Field Exercise \\
\hline & $\begin{array}{c}\text { Promoting Business in Villages/Diversifying Agricultural } \\
\text { Products }\end{array}$ & Lecture/Exercise \\
\hline & & Lecture/Field \\
\hline & Fire Prevention Techniques & Exercise \\
\hline & $\begin{array}{l}\text { Discussion on Non-Burning Agriculture Techniques and } \\
\text { Business }\end{array}$ & Discussion \\
\hline \multirow{3}{*}{ Day 9-10 } & Preparation for Facilitation in Project Target Villages & Exercise \\
\hline & $\begin{array}{c}\text { Presentation on the Plan for Facilitation in Project Target } \\
\text { Villages }\end{array}$ & Presentation \\
\hline & Feedback from the Trainer and Other Participants & Discussion \\
\hline
\end{tabular}

\section{Appendix B. Interview Protocol}

The following are the guiding questions for the interview survey. The first half of the questions are targeted to all respondents, while the second half are only for Village Facilitation Team (VFT) members, who participated in the facilitation training. Since this is a semi-structured interview, the interviewers are expected to flexibly ask questions depending on the reactions or interests of respondents. The interviewer does not have to ask the following questions in this order; the wording can also be flexible. Please try to obtain as much information as possible, particularly on the reasons or values that exist behind their responses.

Questions for all respondents:

(1) Did you participate in the VFT meetings?

(2) Why did you decide to participate in the VFT meetings?

(3) How often/how long did you participate in the VFT meetings?

(4) Who were the attendants of the VFT meetings?

(5) How did you feel when you first attended the meetings?

(6) Did you experience any conflicts with other participants before the VFT meetings?

(7) Among meeting participants, were there anybody with whom you were not familiar?

(8) How did you feel when attending the meetings together with other participants, particularly district government officers?

(9) Did the relationship with other participants, particularly district government officers, change over time through the meetings? If yes, how did it change?

(10) What do you think about the training for non-burning agriculture techniques (e.g. organic fertilizers, organic pesticides)? Was it useful or not?

(11) Were the VFT meetings open to everybody or were they restricted to certain groups of people?

(12) During the VFT meetings, was the information shared equally among all participants?

(13) During the VFT meetings, were participants' opinions listened to and respected by other participants?

(14) Could you understand all the discussions during the VFT meetings? Were there any difficulties in understanding the content of the discussions?

(15) Did you experience any conflicts during the VFT meetings?

(16) How were the VFT members facilitating the discussions?

(17) How were the decisions made during the VFT meetings?

(18) Were there clear rules on how to participate in the VFT meetings?

(19) Did you feel any gaps in knowledge or skills between villagers and district government officers?

(20) If yes, did you feel that the gaps in knowledge or skills changed over time?

(21) If yes, how did they change over time? 
Questions only for VFT members:

(1) Did you participate in the facilitation training programme?

(2) Who were the participants of the facilitation training?

(3) Was there anybody with whom you were not familiar?

(4) How did you feel when participating in the facilitation training together with other participants, particularly district government officers?

(5) How was your relationship with district government officers at the beginning of the training?

(6) Did the relationship with other participants, particularly district government officers, change over time through the training? If yes, how did it change?

(7) What did you think about the content of the training? Was it useful or not?

(8) What kinds of skills/knowledge did you learn from the training programme?

(9) Could you understand the content of the training? Were there any difficulties in understanding the content of the training?

(10) Do you think there were gaps in knowledge or skills between villagers and district government officers?

(11) Was the information or knowledge equally shared with all participants during the facilitation training?

(12) Did you feel that the gaps in knowledge or skills changed over time? If yes, how did they change over time?

\section{Appendix C. Questionnaire Survey Sheet}

Table A2. Questionnaire Survey Sheet.

\begin{tabular}{|c|c|c|c|c|c|c|}
\hline \multirow{2}{*}{ No. } & \multirow[b]{2}{*}{ All/VFT ${ }^{1}$} & \multirow[b]{2}{*}{ Statements } & \multicolumn{4}{|c|}{ Choices } \\
\hline & & & 4: Strongly Agree & 3: Agree & 2: Disagree & 1: Strongly Disagree \\
\hline 1 & VFT & $\begin{array}{l}\text { At the beginning of the facilitation training, I } \\
\text { felt nervous because I was not confident in my } \\
\text { knowledge and skills, compared to the other } \\
\text { participants, particularly district government } \\
\text { officers. }\end{array}$ & 4 & 3 & 2 & 1 \\
\hline & & $\begin{array}{l}\text { At the early stages of the VFT meetings, I felt } \\
\text { nervous because I didn't have enough }\end{array}$ & & & & \\
\hline 2 & All & $\begin{array}{c}\text { knowledge and skills compared to the other } \\
\text { participants, particularly district government } \\
\text { officers. }\end{array}$ & 4 & 3 & 2 & 1 \\
\hline 3 & All & $\begin{array}{l}\text { At the early stages of the VFT meetings, I felt } \\
\text { nervous because there were some people } \\
\text { whom I didn't know well, particularly the } \\
\text { district government officers. }\end{array}$ & 4 & 3 & 2 & 1 \\
\hline 4 & VFT & $\begin{array}{l}\text { participants had equal opportunities to obtain } \\
\text { knowledge and skills. }\end{array}$ & 4 & 3 & 2 & 1 \\
\hline 5 & VFT & $\begin{array}{l}\text { Through the facilitation training, I could obtain } \\
\text { abundant new knowledge and practical skills. } \\
\text { In case some participants had difficulties in }\end{array}$ & 4 & 3 & 2 & 1 \\
\hline 6 & VFT & $\begin{array}{l}\text { keeping up with the training program, } \\
\text { appropriate support was provided by the } \\
\text { trainers. }\end{array}$ & 4 & 3 & 2 & 1 \\
\hline 7 & VFT & $\begin{array}{c}\text { At the end of the facilitation training, there } \\
\text { were little gaps in knowledge or skills among } \\
\text { participants. }\end{array}$ & 4 & 3 & 2 & 1 \\
\hline 8 & All & $\begin{array}{l}\text { During the VFT meetings, information and } \\
\text { knowledge were equally shared with all } \\
\text { participants. }\end{array}$ & 4 & 3 & 2 & 1 \\
\hline 9 & All & $\begin{array}{l}\text { In case some participants had difficulties in } \\
\text { understanding the contents of the discussions, } \\
\text { appropriate support was provided by VFT } \\
\text { members. }\end{array}$ & 4 & 3 & 2 & 1 \\
\hline 10 & All & $\begin{array}{l}\text { I understood almost everything regarding the } \\
\text { topics discussed during VFT meetings. } \\
\text { At the later stages of VFT meetings, there were }\end{array}$ & 4 & 3 & 2 & 1 \\
\hline 11 & All & $\begin{array}{l}\text { little gaps in knowledge or skills among } \\
\text { participants. }\end{array}$ & 4 & 3 & 2 & 1 \\
\hline
\end{tabular}


Table A2. Cont.

\begin{tabular}{|c|c|c|c|c|c|c|}
\hline \multirow{2}{*}{ No. } & \multirow{2}{*}{$\mathrm{All} / \mathrm{VFT}^{1}$} & \multirow{2}{*}{ Statements } & \multicolumn{4}{|c|}{ Choices } \\
\hline & & & 4: Strongly Agree & 3: Agree & 2: Disagree & 1: Strongly Disagree \\
\hline 12 & All & $\begin{array}{l}\text { At the later stages of VFT meetings, I could } \\
\text { express my opinions freely, without being } \\
\text { nervous. }\end{array}$ & 4 & 3 & 2 & 1 \\
\hline 13 & All & $\begin{array}{l}\text { Because some village representatives facilitated } \\
\text { the meetings as VFT members, I felt } \\
\text { comfortable in expressing my opinions. } \\
\text { I participated in VFT meetings to obtain useful }\end{array}$ & 4 & 3 & 2 & 1 \\
\hline 14 & All & $\begin{array}{c}\text { information or knowledge related to my } \\
\text { livelihood. }\end{array}$ & 4 & 3 & 2 & 1 \\
\hline 15 & All & $\begin{array}{l}\text { I participated in VFT meetings because I was } \\
\text { afraid to miss the opportunity to obtain } \\
\text { important information. }\end{array}$ & 4 & 3 & 2 & 1 \\
\hline 16 & All & $\begin{array}{l}\text { I participated in VFT meetings to maintain } \\
\text { good relationships with friends, neighbors, } \\
\text { family members, relatives, village } \\
\text { representatives, or other villagers. }\end{array}$ & 4 & 3 & 2 & 1 \\
\hline 17 & All & $\begin{array}{l}\text { Before joining VFT meetings, I did not } \\
\text { experience conflicts with other participants. } \\
\text { Through joining the facilitation training, I }\end{array}$ & 4 & 3 & 2 & 1 \\
\hline 18 & VFT & $\begin{array}{c}\text { could get to know each other better with the } \\
\text { other participants. }\end{array}$ & 4 & 3 & 2 & 1 \\
\hline 19 & VFT & $\begin{array}{l}\text { At the end of the facilitation training, I was able } \\
\text { to build mutual trust with other participants. } \\
\text { The trainings for non-burning agriculture } \\
\text { techniques (e.g. organic fertilizers, organic }\end{array}$ & 4 & 3 & 2 & 1 \\
\hline 20 & All & $\begin{array}{c}\text { pesticides) strengthened relationships between } \\
\text { VFT members (including district officers) and } \\
\text { other participants. }\end{array}$ & 4 & 3 & 2 & 1 \\
\hline 21 & All & $\begin{array}{l}\text { VFT meetings were open to anybody who was } \\
\text { interested in joining the discussions. }\end{array}$ & 4 & 3 & 2 & 1 \\
\hline 22 & All & $\begin{array}{l}\text { During VFT meetings, most participants joined } \\
\text { the discussions actively. }\end{array}$ & 4 & 3 & 2 & 1 \\
\hline 23 & All & $\begin{array}{c}\text { All participants were treated equally during } \\
\text { VFT meetings. }\end{array}$ & 4 & 3 & 2 & 1 \\
\hline 24 & All & $\begin{array}{c}\text { During VFT meetings, all participants' } \\
\text { opinions were listened to and respected by } \\
\text { other participants. }\end{array}$ & 4 & 3 & 2 & 1 \\
\hline 25 & All & $\begin{array}{l}\text { Participants of VFT meetings made efforts to } \\
\text { respect other participants' opinions even if } \\
\text { they differed from their own opinions. }\end{array}$ & 4 & 3 & 2 & 1 \\
\hline 26 & All & $\begin{array}{l}\text { VFT members made effots to build consensus } \\
\text { by combining all participants' opinions. }\end{array}$ & 4 & 3 & 2 & 1 \\
\hline 27 & All & $\begin{array}{l}\text { Decisions regarding the topics of VFT meetings } \\
\text { were made when most participants attended } \\
\text { meetings. }\end{array}$ & 4 & 3 & 2 & 1 \\
\hline 28 & All & $\begin{array}{l}\text { Most important decisions were made by } \\
\text { villagers, not by VFT members. }\end{array}$ & 4 & 3 & 2 & 1 \\
\hline 29 & All & $\begin{array}{c}\text { There were clear rules regarding how to } \\
\text { participate in discussions during VFT } \\
\text { meetings. }\end{array}$ & 4 & 3 & 2 & 1 \\
\hline 30 & VFT & $\begin{array}{l}\text { During the facilitation training, all the } \\
\text { participants had equal opportunities to obtain } \\
\text { knowledge and skills. }\end{array}$ & 4 & 3 & 2 & 1 \\
\hline 31 & VFT & $\begin{array}{l}\text { Through the facilitation training, I could obtain } \\
\text { abundant new knowledge and practical skills. } \\
\text { Through joining the facilitation training, I }\end{array}$ & 4 & 3 & 2 & 1 \\
\hline 32 & VFT & $\begin{array}{l}\text { could obtain skills on how to combine different } \\
\text { people's ideas and build a consensus. } \\
\text { At the end of the facilitation training, there }\end{array}$ & 4 & 3 & 2 & 1 \\
\hline 33 & VFT & $\begin{array}{l}\text { were little gaps in knowledge or skills among } \\
\text { participants. }\end{array}$ & 4 & 3 & 2 & 1 \\
\hline 34 & All & $\begin{array}{l}\text { Trainings on non-burning agriculture } \\
\text { techniques (e.g. organic fertilizers, organic } \\
\text { pesticides, etc.) provided ideas regarding ways } \\
\text { to tackle the issue of fire. }\end{array}$ & 4 & 3 & 2 & 1 \\
\hline
\end{tabular}

${ }^{1}$ All: All survey respondents' perceptions on VFT meetings; VFT: Village Facilitation Team (VFT) members' perceptions on the facilitation training. 


\section{Appendix D. Questionnaire Survey Results}

Table A3. Questionnaire Survey Results.

\begin{tabular}{|c|c|c|c|c|c|c|}
\hline \multirow{2}{*}{ No. } & \multirow{2}{*}{ All/VFT ${ }^{1}$} & \multirow{2}{*}{ Statements } & \multicolumn{4}{|c|}{ Percentage of Respondents } \\
\hline & & & 4: Strongly Agree & & & 1: Strongly Disagree \\
\hline 1 & VFT & $\begin{array}{l}\text { At the beginning of the facilitation training, I } \\
\text { felt nervous because I was not confident in my } \\
\text { knowledge and skills, compared to the other } \\
\text { participants, particularly district government } \\
\text { officers. }\end{array}$ & $13.8 \%$ & $65.5 \%$ & $17.2 \%$ & $3.4 \%$ \\
\hline 2 & All & $\begin{array}{l}\text { At the early stages of the VFT meetings, I felt } \\
\text { nervous because I didn't have enough } \\
\text { knowledge and skills compared to the other } \\
\text { participants, particularly district government } \\
\text { officers. }\end{array}$ & $6.0 \%$ & $61.0 \%$ & $32.0 \%$ & $1.0 \%$ \\
\hline 3 & All & $\begin{array}{l}\text { At the early stages of the VFT meetings, I felt } \\
\text { nervous because there were some people } \\
\text { whom I didn't know well, particularly the } \\
\text { district government officers. }\end{array}$ & $14.5 \%$ & $62.0 \%$ & $22.0 \%$ & $1.5 \%$ \\
\hline 4 & VFT & $\begin{array}{l}\text { During the facilitation training, all the } \\
\text { participants had equal opportunities to obtain } \\
\text { knowledge and skills. }\end{array}$ & $48.3 \%$ & $51.7 \%$ & $0.0 \%$ & $0.0 \%$ \\
\hline 5 & VFT & $\begin{array}{l}\text { Through the facilitation training, I could obtain } \\
\text { abundant new knowledge and practical skills. } \\
\text { In case some participants had difficulties in }\end{array}$ & $27.6 \%$ & $72.4 \%$ & $0.0 \%$ & $0.0 \%$ \\
\hline 6 & VFT & $\begin{array}{l}\text { keeping up with the training program, } \\
\text { appropriate support was provided by the } \\
\text { trainers. }\end{array}$ & $20.7 \%$ & $58.6 \%$ & $20.7 \%$ & $0.0 \%$ \\
\hline 7 & VFT & $\begin{array}{c}\text { At the end of the facilitation training, there } \\
\text { were little gaps in knowledge or skills among } \\
\text { participants. }\end{array}$ & $24.1 \%$ & $55.2 \%$ & $20.7 \%$ & $0.0 \%$ \\
\hline 8 & All & $\begin{array}{l}\text { During the VFT meetings, information and } \\
\text { knowledge were equally shared with all } \\
\text { participants. }\end{array}$ & $25.0 \%$ & $73.0 \%$ & $2.0 \%$ & $0.0 \%$ \\
\hline 9 & All & $\begin{array}{l}\text { In case some participants had difficulties in } \\
\text { understanding the contents of the discussions, } \\
\text { appropriate support was provided by VFT } \\
\text { members. }\end{array}$ & $14.5 \%$ & $76.0 \%$ & $9.5 \%$ & $0.0 \%$ \\
\hline 10 & All & $\begin{array}{l}\text { I understood almost everything regarding the } \\
\text { topics discussed during VFT meetings. } \\
\text { At the later stages of VFT meetings, there were }\end{array}$ & $5.0 \%$ & $59.0 \%$ & $36.0 \%$ & $0.0 \%$ \\
\hline 11 & All & $\begin{array}{l}\text { little gaps in knowledge or skills among } \\
\text { participants. }\end{array}$ & $3.0 \%$ & $72.0 \%$ & $24.5 \%$ & $0.5 \%$ \\
\hline 12 & All & $\begin{array}{l}\text { At the later stages of VFT meetings, I could } \\
\text { express my opinions freely, without being } \\
\text { nervous. }\end{array}$ & $6.5 \%$ & $72.5 \%$ & $21.0 \%$ & $0.0 \%$ \\
\hline 13 & All & $\begin{array}{l}\text { Because some village representatives facilitated } \\
\text { the meetings as VFT members, I felt } \\
\text { comfortable in expressing my opinions. } \\
\text { I participated in VFT meetings to obtain useful }\end{array}$ & $6.0 \%$ & $88.5 \%$ & $5.5 \%$ & $0.0 \%$ \\
\hline 14 & All & $\begin{array}{c}\text { information or knowledge related to my } \\
\text { livelihood. }\end{array}$ & $27.5 \%$ & $69.5 \%$ & $3.0 \%$ & $0.0 \%$ \\
\hline 15 & All & $\begin{array}{l}\text { I participated in VFT meetings because I was } \\
\text { afraid to miss the opportunity to obtain } \\
\text { important information. }\end{array}$ & $25.0 \%$ & $62.5 \%$ & $12.5 \%$ & $0.0 \%$ \\
\hline 16 & All & $\begin{array}{l}\text { I participated in VFT meetings to maintain } \\
\text { good relationships with friends, neighbors, } \\
\text { family members, relatives, village } \\
\text { representatives, or other villagers. }\end{array}$ & $36.5 \%$ & $63.5 \%$ & $0.0 \%$ & $0.0 \%$ \\
\hline 17 & All & $\begin{array}{l}\text { Before joining VFT meetings, I did not } \\
\text { experience conflicts with other participants. } \\
\text { Through joining the facilitation training, I }\end{array}$ & $40.0 \%$ & $59.0 \%$ & $0.0 \%$ & $1.0 \%$ \\
\hline 18 & VFT & $\begin{array}{l}\text { could get to know each other better with the } \\
\text { other participants. }\end{array}$ & $44.8 \%$ & $55.2 \%$ & $0.0 \%$ & $0.0 \%$ \\
\hline 19 & VFT & $\begin{array}{l}\text { At the end of the facilitation training, I was able } \\
\text { to build mutual trust with other participants. } \\
\text { The trainings for non-burning agriculture }\end{array}$ & $27.6 \%$ & $58.6 \%$ & $13.8 \%$ & $0.0 \%$ \\
\hline 20 & All & $\begin{array}{l}\text { techniques (e.g. organic fertilizers, organic } \\
\text { pesticides) strengthened relationships between } \\
\text { VFT members (including district officers) and } \\
\text { other participants. }\end{array}$ & $58.0 \%$ & $42.0 \%$ & $0.0 \%$ & $0.0 \%$ \\
\hline 21 & All & $\begin{array}{l}\text { VFT meetings were open to anybody who was } \\
\text { interested in joining the discussions. }\end{array}$ & $9.0 \%$ & $62.5 \%$ & $28.5 \%$ & $0.0 \%$ \\
\hline 22 & All & $\begin{array}{l}\text { During VFT meetings, most participants joined } \\
\text { the discussions actively. }\end{array}$ & $9.0 \%$ & $86.5 \%$ & $4.0 \%$ & $0.5 \%$ \\
\hline
\end{tabular}


Table A3. Cont.

\begin{tabular}{|c|c|c|c|c|c|c|}
\hline \multirow{2}{*}{ No. } & \multirow{2}{*}{ All/VFT ${ }^{1}$} & \multirow{2}{*}{ Statements } & \multicolumn{4}{|c|}{ Percentage of Respondents } \\
\hline & & & 4: Strongly Agree & 3: Agree & 2: Disagree & 1: Strongly Disagree \\
\hline 23 & All & $\begin{array}{c}\text { All participants were treated equally during } \\
\text { VFT meetings. }\end{array}$ & $14.5 \%$ & $84.0 \%$ & $1.5 \%$ & $0.0 \%$ \\
\hline 24 & All & $\begin{array}{c}\text { During VFT meetings, all participants' } \\
\text { opinions were listened to and respected by } \\
\text { other participants. }\end{array}$ & $35.5 \%$ & $63.5 \%$ & $1.0 \%$ & $0.0 \%$ \\
\hline 25 & All & $\begin{array}{l}\text { Participants of VFT meetings made efforts to } \\
\text { respect other participants' opinions even if } \\
\text { they differed from their own opinions. }\end{array}$ & $15.0 \%$ & $72.5 \%$ & $12.5 \%$ & $0.0 \%$ \\
\hline 26 & All & $\begin{array}{l}\text { VFT members made effots to build consensus } \\
\text { by combining all participants' opinions. }\end{array}$ & $27.5 \%$ & $71.5 \%$ & $1.0 \%$ & $0.0 \%$ \\
\hline 27 & All & $\begin{array}{l}\text { Decisions regarding the topics of VFT meetings } \\
\text { were made when most participants attended } \\
\text { meetings. }\end{array}$ & $20.0 \%$ & $66.0 \%$ & $14.0 \%$ & $0.0 \%$ \\
\hline 28 & All & $\begin{array}{l}\text { Most important decisions were made by } \\
\text { villagers, not by VFT members. }\end{array}$ & $10.5 \%$ & $56.0 \%$ & $32.5 \%$ & $1.0 \%$ \\
\hline 29 & All & $\begin{array}{c}\text { There were clear rules regarding how to } \\
\text { participate in discussions during VFT } \\
\text { meetings. }\end{array}$ & $5.0 \%$ & $54.5 \%$ & $40.5 \%$ & $0.0 \%$ \\
\hline 30 & VFT & $\begin{array}{l}\text { During the facilitation training, all the } \\
\text { participants had equal opportunities to obtain } \\
\text { knowledge and skills. }\end{array}$ & $48.3 \%$ & $51.7 \%$ & $0.0 \%$ & $0.0 \%$ \\
\hline 31 & VFT & $\begin{array}{l}\text { Through the facilitation training, I could obtain } \\
\text { abundant new knowledge and practical skills. } \\
\text { Through joining the facilitation training, I }\end{array}$ & $27.6 \%$ & $72.4 \%$ & $0.0 \%$ & $0.0 \%$ \\
\hline 32 & VFT & $\begin{array}{c}\text { could obtain skills on how to combine different } \\
\text { people's ideas and build a consensus. } \\
\text { At the end of the facilitation training, there }\end{array}$ & $20.7 \%$ & $69.0 \%$ & $10.3 \%$ & $0.0 \%$ \\
\hline 33 & VFT & $\begin{array}{c}\text { were little gaps in knowledge or skills among } \\
\text { participants. }\end{array}$ & $24.1 \%$ & $55.2 \%$ & $20.7 \%$ & $0.0 \%$ \\
\hline 34 & All & $\begin{array}{l}\text { Trainings on non-burning agriculture } \\
\text { techniques (e.g. organic fertilizers, organic } \\
\text { pesticides, etc.) provided ideas regarding ways } \\
\text { to tackle the issue of fire. }\end{array}$ & $19.0 \%$ & $71.0 \%$ & $10.0 \%$ & $0.0 \%$ \\
\hline
\end{tabular}

${ }^{1}$ All: All survey respondents' perceptions on VFT meetings; VFT: Village Facilitation Team (VFT) members' perceptions on the facilitation training.

\section{References}

1. Ansell, C.; Gash, A. Collaborative governance in theory and practice. J. Public Adm. Res. Theory 2008, 18, 543-571. [CrossRef]

2. Van Oosten, C.; Gunarso, P.; Koesoetjahjo, I.; Wiersum, F. Governing forest landscape restoration: Cases from indonesia. Forests 2014, 5, 1143-1162. [CrossRef]

3. Kelman, C.C. Governance lessons from two sumatran integrated conservation and development projects. Conserv. Soc. 2013, 11, 247-263. [CrossRef]

4. Reed, M.S. Stakeholder participation for environmental management: A literature review. Biol. Conserv. 2008, 141, $2417-2431$. [CrossRef]

5. Innes, J.E.; Booher, D.E. Consensus building and complex adaptive systems: A framework for evaluating collaborative planning. J. Am. Plan. Assoc. 1999, 65, 413-423. [CrossRef]

6. Susskind, L.; Wansem, M.; Ciccarelli, A. Mediating Land Use Disputes-Pros and Cons; Lincoln Institute of Land Policy: Cambridge, MA, USA, 2000.

7. Apgar, J.M.; Cohen, P.J.; Ratner, B.D.; de Silva, S.; Buisson, M.C.; Longley, C.; Bastakoti, R.C.; Mapedza, E. Identifying opportunities to improve governance of aquatic agricultural systems through participatory action research. Ecol. Soc. 2017, 22, 9. [CrossRef]

8. Wondolleck, J.M.; Yaffee, S.L. Making Collaboration Work: Lessons from Innovation in Natural Resource Management; Island Press: Washington, DC, USA, 2000.

9. Frame, T.M.; Gunton, T.I.; Day, J.C. The role of collaborative planning in environmental management: An evaluation of land and resource management planning in British Columbia. J. Environ. Plan. Manag. 2004, 47, 57-82. [CrossRef]

10. Inoue, M.; Shivakoti, G.P. (Eds.) Multi-Level Forest Governance in Asia: Concepts, Challenges and the Way Forward; SAGE Publications: New Delhi, India, 2015; p. 461.

11. Cullen, D.; McGee, G.J.A.; Gunton, T.I.; Day, J.C. Collaborative planning in complex stakeholder environments: An evaluation of a two-tiered collaborative planning model. Soc. Nat. Resour. 2010, 23, 332-350. [CrossRef]

12. Wald, D.M.; Segal, E.A.; Johnston, E.W.; Vinze, A. Understanding the influence of power and empathic perspective-taking on collaborative natural resource management. J. Environ. Manag. 2017, 199, 201-210. [CrossRef] [PubMed]

13. Brown, G.; Harris, C.C. The US forest service: Whither the new resource management paradigm? J. Environ. Manag. 2000, 58, 1-19. [CrossRef]

14. Bodin, O. Collaborative environmental governance: Achieving collective action in social-ecological systems. Science 2017, 357, 6352. [CrossRef] 
15. Gollagher, M.; Hartz-Karp, J. The role of deliberative collaborative governance in achieving sustainable cities. Sustainability 2013, 5, 2343-2366. [CrossRef]

16. Morrison, T.H.; Adger, W.N.; Brown, K.; Lemos, M.C.; Huitema, D.; Hughes, T.P. Mitigation and adaptation in polycentric systems: Sources of power in the pursuit of collective goals. Wiley Interdiscip. Rev. Clim. Change 2017, 8, e479. [CrossRef]

17. Mattijssen, T.J.M.; Buijs, A.A.E.; Elands, B.H.M.; Arts, B.J.M.; van Dam, R.I.; Donders, J.L.M. The transformative potential of active citizenship: Understanding changes in local governance practices. Sustainability 2019, 11, 5781. [CrossRef]

18. Cho, K.W.; Jung, K. From collaborative to hegemonic water resource governance through dualism and jeong: Lessons learned from the daegu-gumi water intake source conflict in Korea. Sustainability 2018, 10, 4405. [CrossRef]

19. Prabowo, D.; Maryudi, A.; Imron, M.A. Conversion of forests into oil palm plantations in west kalimantan, Indonesia: Insights from actor's power and its dynamics. For. Pol. Econ. 2017, 78, 32-39. [CrossRef]

20. Gaventa, J. Finding the spaces for change: A power analysis. IDS Bull. 2006, 37, 23-33. [CrossRef]

21. Brisbois, M.C.; Morris, M.; de Loe, R. Augmenting the IAD framework to reveal power in collaborative governance-An illustrative application to resource industry dominated processes. World Dev. 2019, 120, 159-168. [CrossRef]

22. Brisbois, M.C.; de Loe, R.C. State roles and motivations in collaborative approaches to water governance: A power theory-based analysis. Geoforum 2016, 74, 202-212. [CrossRef]

23. Purdy, J.M. A framework for assessing power in collaborative governance processes. Public Admin. Rev. 2012, 72, 409-417. [CrossRef]

24. Kenney, D.S. Arguing About Consensus: Examining the Case against Western Watershed Initiatives and Other Collaborative Groups Active in Natural Resources Management; Natural Resources Law Center: Boulder, CO, USA, 2000.

25. McDougall, C.; Banjade, M.R. Social capital, conflict, and adaptive collaborative governance: Exploring the dialectic. Ecol. Soc. 2015, 20, 44. [CrossRef]

26. Alam, R.; Lovett, J.C. Prospects of public participation in the planning and management of urban green spaces in Lahore: A discourse analysis. Sustainability 2019, 11, 3387. [CrossRef]

27. Berkes, F. Devolution of environment and resources governance: Trends and future. Environ. Conserv. 2010, 37, 489-500. [CrossRef]

28. Vodden, K. Governing sustainable coastal development: The promise and challenge of collaborative governance in Canadian coastal watersheds. Can. Geogr. 2015, 59, 167-180. [CrossRef]

29. Di Gregorio, M.; Fatorelli, L.; Paavola, J.; Locatelli, B.; Pramova, E.; Nurrochmat, D.R.; May, P.H.; Brockhaus, M.; Sari, I.M.; Kusumadewi, S.D. Multi-level governance and power in climate change policy networks. Global Environ. Chang. 2019, 54, 64-77. [CrossRef]

30. Ensor, J.; Harvey, B. Social learning and climate change adaptation: Evidence for international development practice. WIREs Clim. Chang. 2015, 6, 509-522. [CrossRef]

31. Dewulf, A.; Elbers, W. Power in and over cross-sector partnerships: Actor strategies for shaping collective decisions. Admin. Sci. 2018, 8, 43. [CrossRef]

32. Cook, J.J. Who's pulling the fracking strings? Power, collaboration and Colorado fracking policy. Environ. Pol. Govern. 2015, 25, 373-385. [CrossRef]

33. Hardy, C.; Phillips, N. Strategies of engagement: Lessons from the critical examination of collaboration and conflict in an interorganizational domain. Organ Sci. 1998, 9, 217-230. [CrossRef]

34. Inoue, M. Shinrin shoushitsu mondai heno shiza [Perspectives toward the issue of forest destruction]. In Ajia ni Okeru Shinrin no Shoushitsu to Hozen [Forest Destruction and Conservation in Asia]; Inoue, M., Ed.; Chuohoki: Tokyo, Japan, 2003; pp. 1-10.

35. Sardjono, M.A.; Imang, N. Indonesia I: Review of local community dimensions of forest policies. In Multi-Level Forest Governance in Asia-Concepts, Challenges and the Way Forward; Inoue, M., Shivakoti, G.P., Eds.; Sage: New Delhi, India, 2015; pp. 135-158.

36. Yonariza; Shivakoti, G.P.; Mahdi, M.T.; Yolamalinda. Indonesia III: Characteristics of forest management policy in west sumatra. In Multi-Level Forest Governance in Asia-Concepts, Challenges and the Way Forward; Inoue, M., Shivakoti, G.P., Eds.; Sage: New Delhi, India, 2015; pp. 185-204.

37. Laumonier, Y.; Bourgeois, R.; Pfund, J.L. Accounting for the ecological dimension in participatory research and development: Lessons learned from indonesia and madagascar. Ecol. Soc. 2008, 13, 15. [CrossRef]

38. Mahanty, S.; Guernier, J.; Yasmi, Y. A fair share? Sharing the benefits and costs of collaborative forest management. Int. For. Rev. 2009, 11, 268-280. [CrossRef]

39. Inoue, M. Komonzu no Shisou wo Motomete-Kalimantan no Mori de Kangaeru [Pursuing the Ideology of the Commons-Thoughts from the Forest in Kalimantan]; Iwanami-Shoten: Tokyo, Japan, 2004.

40. Eversole, R. Remaking participation: Challenges for community development practice. Community Dev. J. 2012, 47, 29-41. [CrossRef]

41. JICA. Komyuniti Kyodogata Chihou Gyosei Shien Apurochi Handobukku [A Handbook for Supporting Local Governments Through Community-Based, Collaborative Approach]; Governance Taskforce, Department of Industrial Development and Public Policy, JICA: Tokyo, Japan, 2011.

42. Choi, T.; Robertson, P.J. Deliberation and decision in collaborative governance: A simulation of approaches to mitigate power imbalance. J. Public Admin. Res. Theory 2014, 24, 495-518. [CrossRef] 
43. Diaz-Sarachaga, J.M. Combining participatory processes and sustainable development goals to revitalize a rural area in Cantabria (Spain). Land 2020, 9, 412. [CrossRef]

44. Reed, M.G.; Abernethy, P. Facilitating Co-Production of transdisciplinary knowledge for sustainability: Working with Canadian biosphere reserve practitioners. Soc. Nat. Resour. 2018, 31, 39-56. [CrossRef]

45. Sherriff, S.L.; Miller, H.; Tong, A.; Williamson, A.; Muthayya, S.; Redman, S.; Bailey, S.; Eades, S.; Haynes, A. Building trust and sharing power for co-creation in Aboriginal health research: A stakeholder interview study. Evid. Pol. 2019, 15, 371-392. [CrossRef]

46. Partidario, M.R.; Sheate, W.R. Knowledge brokerage-potential for increased capacities and shared power in impact assessment. Environ. Impact. Assess. Rev. 2013, 39, 26-36. [CrossRef]

47. Levesque, V.R.; Calhoun, A.J.K.; Bell, K.P.; Johnson, T.R. Turning contention into collaboration: Engaging power, trust, and learning in collaborative networks. Soc. Nat. Resour. 2017, 30, 245-260. [CrossRef]

48. Lundsgaard-Hansen, L.M.; Schneider, F.; Zaehringer, J.G.; Oberlack, C.; Myint, W.; Messerli, P. Whose agency counts in land use decision-making in myanmar? A comparative analysis of three cases in Tanintharyi region. Sustainability 2018, $10,3823$. [CrossRef]

49. Page, S.E.; Siegert, F.; Rieley, J.O.; Boehm, H.D.V.; Jaya, A.; Limin, S. The amount of carbon released from peat and forest fires in Indonesia during 1997. Nature 2002, 420, 61-65. [CrossRef] [PubMed]

50. Page, S.E.; Rieley, J.O.; Banks, C. Global and regional importance of the tropical peatland carbon pool. Glob. Chang. Biol. 2011, 17, 798. [CrossRef]

51. Siegert, F.; Ruecker, G.; Hinrichs, A.; Hoffmann, A.A. Increased damages from fires in logged forests during droughts caused by El Niño. Nature 2001, 414, 437-440. [CrossRef]

52. Takahashi, H.; Shimada, S.; Ibie, B.F.; Usup, A.; Yudha, P.; Limin, S.H. Annual change of water balance and drought index in a tropical peat swamp forest of central kalimantan, indonesia. Paper presented at peatlands for People: Natural resource and functions and sustainable management. In Proceedings of the International Symposium on Tropical Peatland, Jakarta, Indonesia, 22-23 August 2001.

53. Varkkey, H. Patronage politics, plantation fires and transboundary haze. Environ. Hazards 2013, 12, 3-4. [CrossRef]

54. Usup, A.; Hashimoto, Y.; Takahashi, H.; Hayasaka, H. Combustion and Thermal characteristics of peat fire in tropical peatland in central kalimantan, Indonesia. Tropics 2004, 14, 1-19. [CrossRef]

55. University of Tanjungpura. Final Report, Fifth Year's Baseline Surveys; Program for Community Development of Fire Control in Peatland Area: Pontianak, Indonesia, 2015.

56. Arai, Y.; Maswadi; Oktoriana, S. Enhancing local community's sense of ownership through international cooperation. Wetl. Res. 2017, 7, 5-16.

57. Lukasiewicz, A.; Baldwin, C. Voice, power, and history: Ensuring social justice for all stakeholders in water decision-making. Local Environ. 2017, 22, 1042-1060. [CrossRef]

58. Tani, T.; Ashida, T. Yokuwakaru Shitsu-Teki Shakai-Chousa [Introduction to Qualitative Social Surveys]; Mineruva-Shobou: Tokyo, Japan, 2015.

59. Lukasiewicz, A.; Bowmer, K.; Syme, G.J.; Davidson, P. Assessing government intentions for australian water reform using a social justice framework. Soc. Nat. Resour. 2013, 26, 1314-1329. [CrossRef]

60. Mizukami, S.; Sakurai, Y. A study on support for dialogues in the workshop as a place for cooperative learning-focusing on intrinsic motivation. J. Arch. Plan. 2013, 78, 735-744. [CrossRef]

61. Umans, L. Intervention, facilitation and self-development: Strategies and practices in forestry cooperation in Bolivia. Dev. Chang. 2012, 43, 773-795. [CrossRef]

62. Sasaki, H. Fasiliteita Gainen ni Kansuru Rironteki Kosatsu [A Theoretical Consideration on the Concept of Facilitation]; Bulletin of the Education Center; Faculty of Education, Utsunomiya University: Utsunomiya City, Japan, 2011; pp. 129-136.

63. Ohmoto, Y.; Toda, Y.; Ueda, K.; Nishida, T. Giron heno sanka taido to higengo joho ni motozuku fasiliteishon no bunseki [Analyses of the facilitating behavior by using participant's agreement and non-verbal behavior]. J. Inf. Process. 2011, 52, 3659-3670.

64. Hori, K. Mondai Kaiketsu Fasiliteitaa: Fasiliteishon Yousei Koza [Problem Solving Facilitator: A Training Course for Facilitation]; Toyo-Keizai Shinposha: Tokyo, Japan, 2000.

65. Mikami, N. Chikyuu kibo deno shimin sanka ni okeru fasiliteitaa no yakuwari-chikyuu ondanka ni kansuru sekai shimin kaigi (WWViews) wo jirei to shite [The role of facilitators in global-scale public participation exercises: A case study on world wide views on global warming]. Jpn. J. Sci. Comm. 2010, 7, 19-32.

66. Fujisawa, T.; Hideshima, E.; Kitamura, N. Chiiki shakai no kadai kaiketsu ni muketa juumin togi purosesu ni kansuru jikkenteki bunseki [An experimental analysis for process of discussion by residents to solve regional problem]. Sociotechnica 2008, 5, 88-95. [CrossRef]

67. Rixon, A.; Smith, T.F.; McKenzie, B.; Sample, R.; Scott, P.; Burn, S. Perspectives on the art of facilitation: A Delphi study of natural resource management facilitators. Australas. J. Environ. Manag. 2007, 14, 179-191. [CrossRef]

68. Gunton, T.I.; Day, J.C. The theory and practice of collaborative planning in resource and environmental management. Environments 2003, 31, 5-20.

69. Abe, H.; Yuzawa, A. Waaku shoppu ni okeru goi keisei purosesu no hyouka [An evaluation of consensus making in workshop]. J. City Plan. Inst. Jpn. 2001, 10, 55-60. 
70. Begg, C. Power, responsibility and justice: A review of local stakeholder participation in European flood risk management. Local Environ. 2018, 23, 383-397. [CrossRef]

71. Tsubouchi, A. Naze PLA nanoka- kaihatsu ni okeru paradaimu tenkan no hitsuyosei, zoku nyuumon shakai kaihatsu- pla: Juumin shutai no gakushuu to kodo niyoru kaihatsu [why pla? the need for a paradigm shift in development. In Introduction to Social Development-PLA: Development Through Community-Based Learning and Action]; Project, P.L.A., Ed.; International Development Journal Ltd: Tokyo, Japan, 2000; pp. 202-217.

72. Stern, M.J.; Coleman, K.J. The multidimensionality of trust: Applications in collaborative natural resource management. Soc. Nat. Resour. 2015, 28, 117-132. [CrossRef]

73. Ran, B.; Qi, H.T. The entangled twins: Power and trust in collaborative governance. Admin. Soc. 2019, 51, 607-636. [CrossRef]

74. Riggs, R.A.; Langston, J.D.; Margules, C.; Boedhihartono, A.K.; Lim, H.S.; Sari, D.A.; Sururi, Y.; Sayer, J. Governance challenges in an eastern indonesian forest landscape. Sustainability 2018, 10, 169. [CrossRef] 